\title{
Do understory sapling respond to both light and below-ground competition?: a field experiment in a north-eastern American hardwood forest and a literature review
}

\author{
Jean-Pierre RICARD, Christian MessieR*, Sylvain DelagRange, Marilou BeAUdeT \\ Groupe de Recherche en Écologie Forestière Interuniversitaire, Département des Sciences Biologiques, Université du Québec à Montréal, \\ CP 8888, succursale Centre-Ville, Montréal, Québec, Canada, H3C 3P8
}

(Received 14 May 2002; accepted 4 November 2002)

\begin{abstract}
A study was initiated in 1993 to evaluate the potential effects of both above- and below-ground competition exclusion on yellow birch (Betula alleghaniensis Britton), sugar maple (Acer saccharum Marsh.) and American beech (Fagus grandifolia Ehrh.) sapling growth along an understory light gradient ranging from $3 \%$ to $50 \%$ of full sunlight. We compared four different growth variables between a control and a treatment (trenching and manual removal of nearby vegetation). Height growth, diameter growth, height over stem diameter ratio, and crown area varied with light availability in all three species, whereas trenching treatment had no significant effect. Our results show that light is the main factor affecting understory sapling growth following a selection cut in this northern hardwood forest, at least up to $50 \%$ full sunlight. The unresponsiveness of these three species to below-ground competition is discussed in relation to a literature review in which both soil richness and species functional ecology are considered.
\end{abstract}

above- and below-ground competition / growth / light / northern hardwood species / trenching

Résumé - Les gaulis en sous couvert répondent-ils à la fois à une compétition en dessous et au-dessus du sol ? Une expérience en forêt feuillue du Nord-Est de l'Amérique et une revue de littérature. En 1993, une étude a été entreprise afin de déterminer les effets éventuels de l'élimination de la compétition souterraine sur la croissance de gaulis de bouleau jaune (Betula alleghaniensis Britton), d'érable à sucre (Acer saccharum Marsh.) et de hêtre à grandes feuilles (Fagus grandifolia Ehrh.) se trouvant sous un gradient de lumière allant de $3 \%$ à $50 \%$ du rayonnement solaire total. Quatre paramètres de croissance ont été comparés entre des gaulis témoins et des gaulis traités (création d'une tranchée et enlèvement manuel des tiges avoisinantes). Pour les trois espèces, les croissances en hauteur et en diamètre, le ratio hauteur sur diamètre de la tige et la surface de cime ont varié avec la disponibilité en lumière, alors que l'élimination de la compétition n'a eu aucun effet. Nos résultats suggèrent donc que la lumière est le principal facteur limitant la croissance des gaulis en sous-couvert après une coupe de jardinage dans cette forêt feuillue tempérée, au moins jusqu'à $50 \%$ de pleine lumière. La faible réponse des trois espèces à l'élimination de la compétition est discutée à partir d'une revue de littérature dans laquelle la fertilité des sols et le comportement écologique des espèces sont comparés.

compétition au-dessus et en dessous du sol / croissance / lumière / espèces feuillues tempérées / élimination de la compétition souterraine

\section{INTRODUCTION}

In north-eastern American hardwood forests, understanding the response of understory trees to small canopy openings is important in order to carry out partial cutting that allows the regeneration and growth of a variety of tree species. Over the last decade, many studies have focussed on the relationship between light availability in gaps of various sizes and understory tree growth and physiology $[3-6,8,11,12,14,25,26$, $29,36,46,47]$. All of these studies have reported that increased light availability, as found in small to medium canopy openings, was a major factor affecting seedling and sapling growth.
However, below-ground resource availability is also believed to affect plant growth and species composition [18, $24,31,52,55]$. In a temperate oldfield, Putz and Canham [51] found that saplings of red maple (Acer rubrum L.) did not respond to canopy openings, but responded to a reduction in root competition. In another ecosystem, Christy [17] found that growth of understory western hemlock seedlings (Tsuga heterophylla Raf. [Sarg.]) was mainly affected by belowground competition reduction and to a much lesser extent by an increase in light availability. While some studies have reported that root competition is a major factor affecting plant performance $[23,40,41,56]$, many others have found either

* Corresponding author: messier.christian@uqam.ca 
Table I. Characteristics of sampled saplings prior to the experiment in 1993 at the Duchesnay experimental forest near Québec, Canada. Mean with standard errors in parentheses.

\begin{tabular}{lccccc}
\hline Species & Treatment & $n$ & Sapling age in 1993 & Initial height in 1993 $(\mathrm{cm})$ & Initial diameter in 1993 (cm) \\
\hline Yellow birch & control (NT) & 39 & $7.9(3.0)$ & $124.9(31.6)$ & $1.27(0.36)$ \\
Sugar maple & trenched (T) & 36 & $7.7(2.9)$ & $112.4(27.0)$ & $1.37(0.39)$ \\
& control (NT) & 37 & $11.4(2.5)$ & $104.0(25.0)$ & $1.06(0.30)$ \\
American beech & trenched (T) & 35 & $12.8(3.9)$ & $112.1(26.0)$ & $1.21(0.31)$ \\
& control (NT) & 34 & $11.1(3.3)$ & $125.2(33.4)$ & $1.55(0.54)$ \\
\hline
\end{tabular}

no real effect of trenching or fertilisation on plant growth [21, $22,33,51]$ or a better growth release when both above- and below-ground competition were removed [15, 22, 43, 50].

Studies that have investigated a large number of temperate and tropical tree species $[18,42]$ have also shown a variation in species response to increased above- and below-ground resources. These variations may be associated with the variation in shade tolerance: growth of shade intolerant species is affected by limited resource whereas growth of shade tolerant species is less affected owing to the slower growth rates and/or high storage capacities of these latter species [9, 16].

All of these studies and a recent review by Coomes and Grubb [19] seem to indicate that the relative importance of above- and below-ground competition for understory tree growth is very dependent on the site conditions and/or the species investigated. In fact, (1) understory trees growing on nutrient poor and dry sites tend to be more affected by belowground competition than trees growing on sites that are not nutrient- or water-limited [19, 31, 45, 53], and (2) pioneer or shade intolerant species tend to be more sensitive to belowground competition [16].

The objective of this study was to examine the relative importance of both above- and below-ground competition on the growth of well-established understory sugar maple (Acer saccharum Marsh.), American beech (Fagus grandifolia Ehrh.) and yellow birch (Betula alleghaniensis Britton) saplings which are found naturally coexisting in hardwood forests of north-eastern America. Of these three species, yellow birch is considered the most shade intolerant, whereas sugar maple and American beech are considered to be shadetolerant and very shade-tolerant, respectively $[1,10,13,28$, 30, 35, 54]. This study addresses three specific questions: (1) do understory vegetation and below-ground competition affect understory sapling height and diameter growth, (2) does this change with increasing gap size as measured by light availability, and (3) are shade intolerant species more affected by above- and below-ground competition? We then reviewed the results obtained in several studies done on this subject, as well as the conditions under which the studies were performed, to improve our understanding of the conditions under which exclusion of understory vegetation and below-ground competition may or may not be important for understory tree saplings.

\section{MATERIALS AND METHODS}

\subsection{Study area}

The study site was located at the Duchesnay experimental forest ( $46^{\circ} 55^{\prime} \mathrm{N}, 71^{\circ} 40^{\prime} \mathrm{W}$ ) near Québec, Canada. The mean annual precipitation is approximately $1220 \mathrm{~mm}$ and mean daily temperature ranges from $-12{ }^{\circ} \mathrm{C}$ in January to $28^{\circ} \mathrm{C}$ in July [27]. Elevation ranges from 200 to $300 \mathrm{~m}$, and slopes are generally gentle (2-20\%). The humus layer was thin and of the moder type. Soils developed on a well-drained to imperfectly drained glacial till. Soil types ranged from drystic brunisols to humo-ferric podzols. The overstory canopy was dominated by sugar maple, American beech and yellow birch which respectively accounted for 60,20 and $15 \%$, respectively, of the merchantable volume. A selection cut was performed at the study site in 1989 , where $30 \%$ of the total tree basal area was harvested. This cut created several gaps ranging in size from approximately $10 \mathrm{~m}^{2}$ to $300 \mathrm{~m}^{2}$. The main woody species present in the understory prior to the partial cut were Canadian yew (Taxus canadensis L.), striped maple (Acer pensylvanicum L.), mountain maple (Acer spicatum Lam.), sugar maple, American beech and yellow birch. Following the cut, early successionnal species such as red raspberry (Rubus idaeus L.) and pin cherry (Prunus pensylvanica L.f.) established in and around gaps.

\subsection{Sapling selection and treatments}

Fourteen gaps, with similar aspects and slopes, were selected in the partially cut area and in an adjacent undisturbed area of the stand to cover a wide gradient of canopy opening sizes and light availability (3 to $50 \%$ of above-canopy PPFD: Photosynthetic Photon Flux Density). Seventy-two (72) sugar maple, 63 beech, and 75 yellow birch saplings were selected. All selected saplings were dominant relative to the surrounding vegetation. Table I presents their average age, height and diameter at the start of the experiment. The removal of understory vegetation and trenching treatment was applied to half the saplings, by manually removing all above-ground vegetation and by trenching in a $1 \mathrm{~m}$ radius zone around each sapling to a depth of 30 to $40 \mathrm{~cm}$. Trenching was carried out at the beginning of May 1993 and 1994, as well as in July 1993, 1994 and 1995 to avoid root incursion from adjacent understory vegetation and overstory trees. New growth or establishment of vegetation in the 1 meter radius zone was also manually eliminated as needed. This treatment was aimed at eliminating below-ground competition from both the overstory trees and non-shading understory vegetation. Non-shading understory vegetation was abundant around all selected saplings and composed mainly of tree seedlings and saplings (4 to $75 \mathrm{stems} / \mathrm{m}^{2}$ ), early and late successional shrubs ( 0 to $126 \mathrm{stems} / \mathrm{m}^{2}$ ) and various herb species (5 to $75 \%$ cover). 


\subsection{Growth and light measurements}

All saplings were sampled at the end of the 1995 growing season, after three full years of growth following the initial treatment. Annual height growth for the three years following the treatment and the three years before the treatment was estimated from bud scars. Sapling stem diameter growth at the forest floor was measured under binoculars by measuring rings located on two perpendicular lines, from the centre of the stem to the bark. A mean was then calculated from both lines to avoid incorrect estimations resulting from irregular diameter growth. Sapling height over stem diameter ratio was calculated for each sapling, based on its dimension at the end of the 1995 growing season. At the same time, crown area was estimated in a quick way as the product of two perpendicular diameter measurements, one of which was the maximum crown diameter.

Understory percent PPFD was measured above all saplings using the method proposed by Messier and Puttonen [44] and tested by Parent and Messier [49] and Gendron et al. [32]. On three completely overcast days, three instantaneous light measurements were taken at 5-10 $\mathrm{cm}$ above each sapling $\left(\mathrm{I}_{\mathrm{u}}\right)$, using a LI-189 light radiometer (LICOR, Lincoln, Nebraska, USA). A quantum sensor linked to a LI-1000 datalogger (LI-COR) was placed in an adjacent clear-cut to record the overstory PPFD conditions $\left(\mathrm{I}_{\mathrm{O}}\right)$. The datalogger was programmed to compute the mean PPFD $\left(\mu \mathrm{mol} \mathrm{m} \mathrm{m}^{-2} \mathrm{~s}^{-1}\right)$ measured every 10 seconds over a one-minute period. The $\mathrm{I}_{\mathrm{u}}$ value obtained at a certain time was divided by $\mathrm{I}_{\mathrm{O}}$ recorded at the same time (and multiplied by 100) to calculate the percent of above canopy PPFD (\% PPFD) above each sapling. According to Messier and Puttonen [44], Parent and Messier [49] and Gendron et al. [32], such instantaneous measurements obtained under completely overcast sky conditions are highly related to the mean daily percent PPFD measured under both overcast and clear sky conditions.

\subsection{Soil water, nutrient and temperature measurements}

Soil water content, nutrient availability and temperature were measured in early August and late September 1993, at the end of the first growing season after treatment, in order to evaluate the effects of the understory vegetation removal and trenching treatment. Three to four subsamples of soil taken within $40 \mathrm{~cm}$ of each replicated sapling were bulked together into one sample. We sampled the soil around 15 treated and 15 untreated saplings selected at random in August and the same number in September 1993 among the 216 saplings used in this study. Soil samples were sifted in order to keep only the fine mineral soil. Water content ( $\%$ of dry weight), soil temperature measured at $10 \mathrm{~cm}$, nitrogen availability $\left(\mathrm{NH}_{4}^{+}\right.$et $\left.\mathrm{NO}_{3}^{-}\right)$and total phosphorus $\left(\mathrm{PO}_{4}^{2-}\right)$ were measured for each soil sample. $\mathrm{KCl}$ was used for $\mathrm{N}$ extraction while Bray II ( $\mathrm{NH} 4 \mathrm{~F}$ et $\mathrm{HCl})$ method was employed for $\mathrm{P}$ extraction.

\subsection{Data analysis}

Sapling height and diameter growth for the three years before the removal of understory vegetation and trenching treatment (1990 to 1992 ) initiation were investigated to test for any prior growth differences between the control and trenched treatments. No significant difference was found between treatments for any of the three species $(P>0.60)$. Consequently, equation (1) was used to calculate the relative height increment, and equation (2) was used for the relative diameter increment. These equations of relative increment allowed us to take into account the slight differences in initial height and basal stem diameter that were present among study saplings (see Tab. I).

Relative height increment $=\left[\left(\right.\right.$ Height ${ }_{95}-$ Height $\left.{ }_{92}\right) /$ Height 92$] \times 100$

Relative diameter increment $=\left[\left(\right.\right.$ Diameter $_{95}-$ Diameter $\left._{92}\right) /$ Diameter $\left._{92}\right]$

$$
\times 100
$$

where Height 92 and Diameter 92 are measurements before treatment, and Height ${ }_{95}$ and Diameter ${ }_{95}$ are measurements three growing seasons after treatment initiation.

Analysis of covariance (ANCOVA) using General Linear Models (SYSTAT v.8.0 [SPSS Science, Chicago, Illinois]) was performed to evaluate the effects of the treatment and species on sapling parameters (relative height increment, relative diameter increment, height/ diameter ratio in 1995, and crown area in 1995). In all cases, \%PPFD was used as a covariable whereas treatments and species were used as grouping factors. Slopes were considered significantly different when the probability associated to the interaction terms $(\%$ PPFD $\times$ treatment, or \%PPFD $\times$ species) was lower than 0.05. A T-test with unequal variance was used to evaluate the effect of trenching on the various soil parameters.

Logarithmic transformation $\left(\log _{10}[\mathrm{x}+1]\right)$ had to be performed on the four dependent variables and on the independent variable (PPFD) to meet statistical assumptions (residuals normality, homogeneity of variance and data linearity). Transformations were also used in some cases for the soil parameters to meet statistical assumptions.

\section{RESULTS}

Available nitrate $\left(\mathrm{NO}_{3}^{-}\right)$was slightly higher for treated saplings $(70.99 \mathrm{mg} / \mathrm{L})$ compared to the control ones $(58.53 \mathrm{mg} / \mathrm{L})$, but these differences were not significant $(P=0.1338)$. Furthermore, we found no changes in ammonium $\left(\mathrm{NH}_{4}^{+}\right)($control $=$ $281.87 \mu \mathrm{g} / \mathrm{L}$, treated $=281.07 \mu \mathrm{g} / \mathrm{L} ; P=0.9766)$ and soil water availability (control $=52.35 \%$, treated $51.07 \% ; P=0.4393$ ) between treatments. Total phosphorus $(\mathrm{P})$ was not influenced by the trenching and understory competition removal treatment (control $=0.151 \mu \mathrm{g} / \mathrm{g}$, trenched $0.164 \mu \mathrm{g} / \mathrm{g} ; P=0.4014$ ). Finally, soil temperature was slightly, but significantly higher near the treated compared to the untreated saplings.

The general linear model (Tab. II) indicated a few significant interactions between species and light for three variables (relative height and diameter increment, and height over diameter ratio). In all three species, relative height increment increased with increasing light, but the increase was the strongest for sugar maple and the weakest for American beech (Fig. 1A; Tab. II: interaction term $\mathrm{Sp} \times \mathrm{L}$ ). Also, in all three species, the relative diameter increment increased with increasing light, but the increase was clearly stronger for yellow birch compared to the other two species (Fig. 1B; Tab. II: interaction term $\mathrm{Sp} \times \mathrm{L}$ ). The height over stem diameter ratio decreased with increasing light in all three species, but the decrease was much stronger for American beech (Fig. 2A; Tab. II: interaction term $\mathrm{Sp} \times \mathrm{L})$. Finally, the crown area increased with increasing light and the slopes were parallel among the three species (Fig. 2B; Tab. II: interaction term Sp $\times$ L not significant). While light availability had a strong effect on all four growth variables, we did not find any effect of the below-ground exclusion treatment. The $F$ values associated with the below-ground exclusion treatment effect and the interaction terms were all low (generally lower than 2) and the $P$ values all higher than 0.125 (Tab. II).

\section{DISCUSSION}

Our three objectives were to determine if the exclusion of below-ground competition would affect sapling height and diameter growth, if the effect would vary depending on light 
Table II. Summary (degree of freedom; $d f, F$ value and probability; $p$ ) of analysis of variance of relative height increment, relative diameter increment, height over stem diameter ratio, and crown area. Values in bold are significant at $\alpha=0.05$.

\begin{tabular}{|c|c|c|c|c|c|c|c|c|c|c|c|c|}
\hline \multirow{2}{*}{ Source of variation } & \multicolumn{3}{|c|}{ Relative height increment } & \multicolumn{3}{|c|}{ Relative diameter increment } & \multicolumn{3}{|c|}{ Height/diameter ratio } & \multicolumn{3}{|c|}{ Crown area } \\
\hline & $d f$ & $F$ & $P$ & $d f$ & $F$ & $P$ & $d f$ & $F$ & $P$ & $d f$ & $F$ & $P$ \\
\hline Species (Sp.) & 2 & 13.39 & $<0.001$ & 2 & 0.79 & 0.457 & 2 & 0.71 & 0.493 & 2 & 0.68 & 0.507 \\
\hline Treatment $(\mathrm{T})$ & 1 & 1.83 & 0.178 & 1 & 0.11 & 0.744 & 1 & 1.18 & 0.279 & 1 & 0.14 & 0.714 \\
\hline Light (L) & 1 & 186.52 & $<0.001$ & 1 & 142.26 & $<0.001$ & 1 & 37.90 & $<0.001$ & 1 & 37.95 & $<0.001$ \\
\hline Sp. $\times \mathrm{T}$ & 2 & 0.02 & 0.980 & 2 & 0.14 & 0.871 & 2 & 0.14 & 0.868 & 2 & 1.59 & 0.207 \\
\hline Sp. $\times$ L & 2 & 6.69 & 0.002 & 2 & 7.61 & 0.001 & 2 & 3.16 & 0.045 & 2 & 0.43 & 0.650 \\
\hline $\mathrm{L} \times \mathrm{T}$ & 1 & 1.77 & 0.185 & 1 & 0.03 & 0.866 & 1 & 2.38 & 0.125 & 1 & 0.61 & 0.434 \\
\hline Sp. $\times \mathrm{T} \times \mathrm{L}$ & 2 & 0.23 & 0.796 & 2 & 0.13 & 0.881 & 2 & 0.39 & 0.676 & 2 & 1.36 & 0.259 \\
\hline Error & 175 & & & 179 & & & 166 & & & 193 & & \\
\hline
\end{tabular}

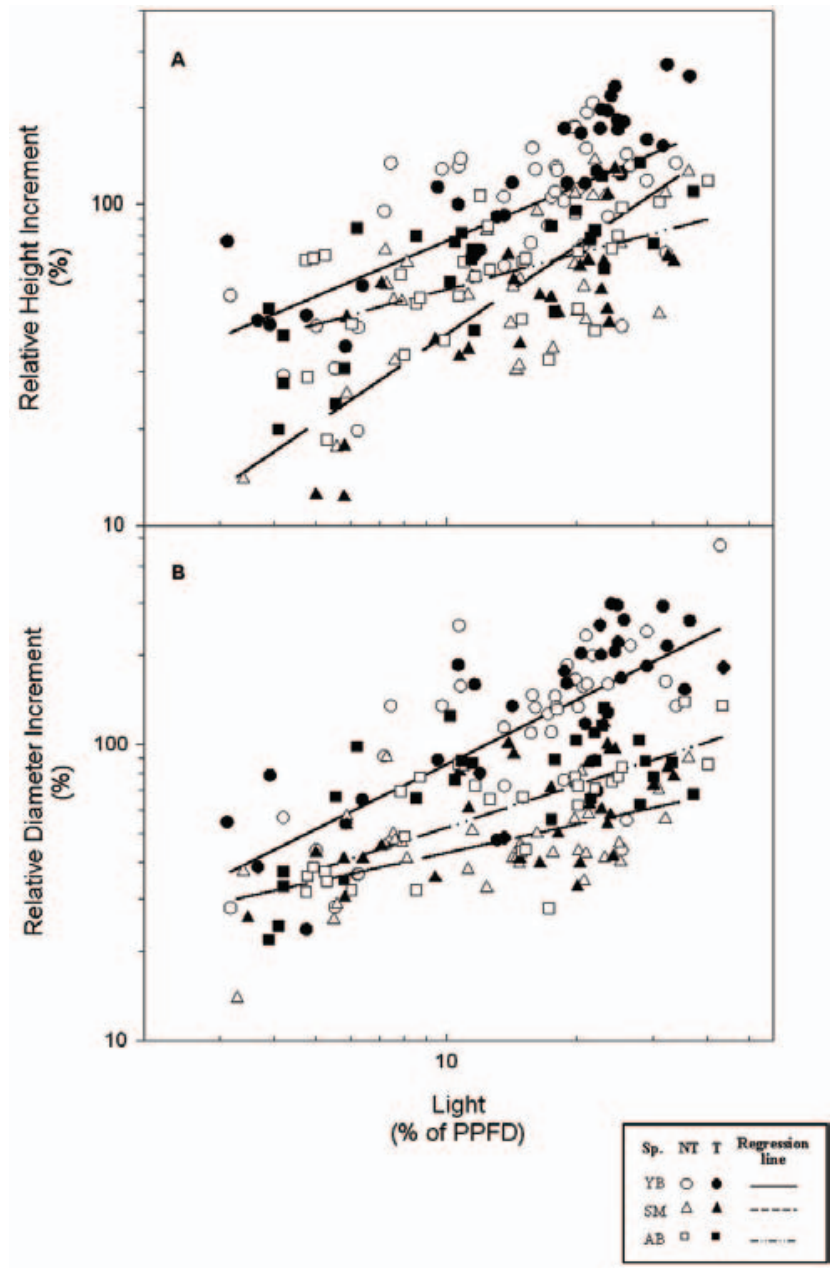

Figure 1. Linear relationships between mean daily percent PPFD and $(\mathbf{A})$ relative height increment, and $(\mathbf{B})$ relative diameter increment (logarithmic scale for both axes). Saplings of yellow birch (YB; circles), sugar maple (SM; triangles) and American beech (AM; squares) were separated in treated (T; filled symbols) and non-treated (NT; open symbols) saplings. As treatment had no effect on relative height growth of our three species, regression lines were drawn for each species after grouping treated and non-treated saplings in a single group.

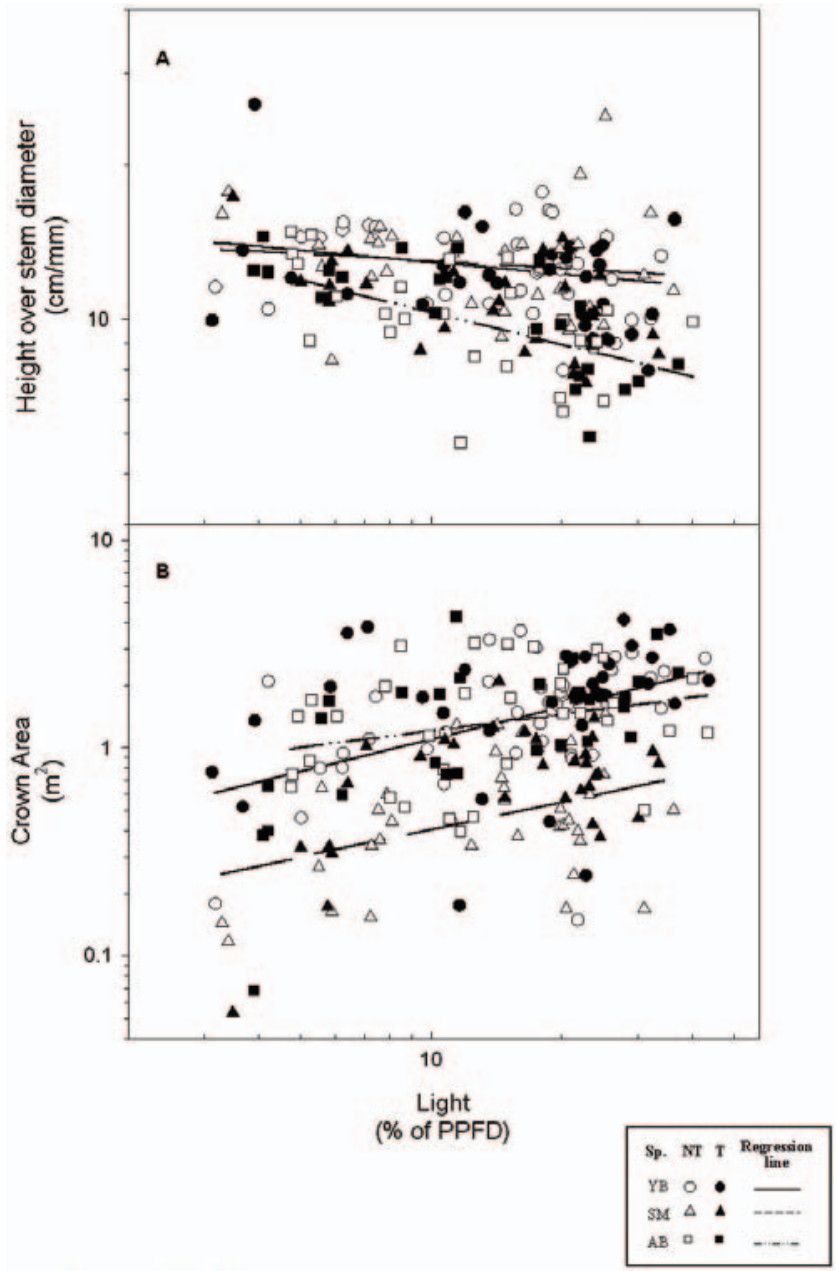

Figure 2. Linear relationships between mean daily percent PPFD and (A) height over stem diameter ratio and (B) crown area (logarithmic scale for both axes). Saplings of yellow birch (YB; circles), sugar maple (SM; triangles) and American beech (AM; squares) were separated in treated (T; filled symbols) and non-treated (NT; open symbols) saplings. As treatment had no effect, regression lines were drawn for each species after grouping treated and non-treated saplings in a single group. 
availability and if less shade tolerant species would be more affected than more tolerant species. Our results showed that the below-ground exclusion treatment did not have any effect on height and diameter increment, height over diameter ratio or crown area, and that this was true under all light conditions (up to $50 \%$ light) and for all three species.

We expected that the exclusion of below-ground competition would increase nutrient and water availability through the elimination of below-ground competition for those resources. A more or less rapid decomposition of the trenched dead fineroots could also have led to an increase in nutrient availability over time. Since we did not observe any effect of the belowground exclusion treatment, we considered the possibility that the treatment may have had other effects than simply increasing nutrient and water availability. The elimination of the understory vegetation surrounding each treated sapling may have led to an increased exposure of the soil to solar radiation, to an increase in soil temperature, and an increased rate of evaporation. However, since precipitation are relatively abundant in our study area, and well distributed during the whole growing season, we think it is unlikely that the treatment led a water stress for treated saplings. The trenching treatment may also have destroyed some exploratory roots and mycorrrhizal connections that normally expand beyond $1 \mathrm{~m}$ from those saplings. Although this remains possible, preliminary investigation on a few saplings of similar size indicated that roots longer than $1 \mathrm{~m}$ in length were very rare. Therefore, we feel very confident that our treatment should have increased the overall availability of below-ground resources, especially nutrient availability. This concurs with the review made by Coomes and Grubb [19].

Our findings therefore clearly demonstrate the overriding importance of the above-ground resource (i.e. light availability) for all four growth variables investigated in this study, for all three hardwood species, at least up to the sapling stage (between 50 and $200 \mathrm{~cm}$ in height), and for up to $50 \%$ light availability. It is possible, however, that at higher light levels as found in clearcut areas that below-ground competition may occur. This concurs with results reported in several other studies done in the same area $[3,5,6]$. However, the overall lack of responsiveness of our three species contradicts many studies that have found significant effects of understory vegetation and belowground competition exclusion treatment [17, 18, 40, 41, 48, 56].

To improve our understanding of the conditions under which exclusion of understory vegetation and below-ground competition may or may not be important for understory tree saplings, we reviewed the results obtained in several studies done on this subject, as well as the conditions under which the studies were performed (Tab. III). From this literature review, it becomes evident that simultaneous growth limitation by both above- and below-ground competition ( $\mathrm{A}>\mathrm{B}, \mathrm{A}<\mathrm{B}$, or $\mathrm{A}=\mathrm{B}$ in Tab. III) is not an exceptional situation, as proposed by Gleeson and Tilman [34]. However, except in a few studies [42, 43, 50], above- and below-ground competition usually do not equally affect growth, and their relative importance appears to be related to soil conditions. The results obtained in numerous studies done in very contrasting forest ecosystems (Tab. III) indicate a predominance for below-ground competition in sites with soils of low fertility, such as sandy arid soils [2, 41, 48], abandoned oldfield [51, 56], boreal [40], coniferous forest [17] and disturbed tropical forests $[18,20]$. On the other hand, in many tropical $[21,22,38,46]$ and hardwood temperate ([37, this study) forests, where the soils are rich and where precipitation is abundant, above-ground competition (i.e. light availability) is clearly the main factor affecting understory sapling growth (A; no B in Tab. III). Interestingly, very similar conclusions were obtained independently by Coomes and Grubb [19] in their recent review of the impacts of root competition in forests.

In this review, we have also looked for a possible pattern of response in relation to the successional or tolerance status of the tree species investigated. Such a pattern, if it exists, is not completely clear from this review. However, there appears to be a slightly greater response to below-ground competition [22, $39,46]$, and more globally a higher growth response to both above- and below-ground competition removal [22, 39, 42, 43], for early successional and rather shade intolerant species [19]. According to Chapin [16], this could be due to the higher growth rates of shade intolerant species which require more resources to grow and develop. However, a lack of growth response in shade tolerant species when below-ground resources increase do not necessarily mean that such trees did not respond to an increase in those resources. Burslem et al. [9] and Coomes and Grubb [18] have observed that such species could increase nutrient storage, number of leaves or branch length after trenching without any critical growth response.

Therefore, considering that precipitation in our study area is fairly high (i.e. approximately $1220 \mathrm{~mm} / \mathrm{year}$ ) and well distributed throughout the growing season, and that the soil is relatively nutrient rich (dystric brunisol to humo-ferric podzol), it is not surprising that our understory vegetation and belowground competition exclusion treatment did not produce any strong growth response. Bellefleur and Pétillon [7], who studied the growth of the same three species, but at the seedling stage, following the elimination of understory vegetation over 3 years in the same area, also reported that soil moisture was not a limiting factor for the growth of these same three species.

\section{CONCLUSION}

Our results suggest that the exclusion of the understory vegetation and below-ground competition in this northern hardwood forest does not improve the understory soil conditions enough to trigger any significant changes in growth for any of the three species investigated in this study. Furthermore, we did not find any measurable threshold of light availability (up to $50 \%$ light availability) at which the effects of the treatment became significant (i.e. no light $\times$ treatment interaction). A thorough review of the literature on this subject also indicated that understory tree saplings respond to the elimination of below-ground competition only in relatively nutrient poor and/or dry sites. Therefore, given the relatively nutrient rich soil and wet conditions in this study, light is the overriding factor limiting understory tree growth, at least up to the sapling stage and up to $50 \%$ light availability. 
Table III. Literature review of the relative importance and strength of the effects of both above- and below-ground competition on the growth response of understory trees in various forest ecosystems and soil conditions. The table includes: authors, types of treatment applied to separate the below-ground effects from the above-ground effect, types of forest and soil conditions of the study, tree species investigated with a rough classification of their shade tolerance level, and a summary of (1) the relative response to both above (A)- and below (B)-ground competition and, (2) the overall strength of the response. References were ranked in a decreasing importance of above-ground competition importance (column 5).

\begin{tabular}{|c|c|c|c|c|}
\hline Reference & Treatment applied & $\begin{array}{l}\text { Forest and Soil } \\
\text { conditions * }\end{array}$ & Species & $\begin{array}{l}\text { Relative and strength } \\
\text { of the response \# }\end{array}$ \\
\hline $\begin{array}{l}\text { Ricard et al. } \\
\text { (this study) }\end{array}$ & $\begin{array}{l}\text { Trenching and Gradient } \\
\text { of light regimes }\end{array}$ & Temperate hardwood forest (Quebec, Ca) & $\begin{array}{l}\text { Tol (Fagus grandifolia, Acer saccharum) } \\
\text { Mid (Betula alleghaniensis) }\end{array}$ & $\begin{array}{l}\text { A; (no B) - Low } \\
\text { A; (no B) - Medium }\end{array}$ \\
\hline Denslow et al., 1990 & $\begin{array}{l}\text { Fertilisation and Contrasting loca- } \\
\text { tion in forest (gap centre, gap edges } \\
\text { and adjacent understory) }\end{array}$ & Tropical wet forest (Costa Rica) & $\begin{array}{l}\text { Tol (Miconia gracilis, Piper arieianum, Piper } \\
\text { urostachyum) } \\
\text { Mid (Miconia nervosa) } \\
\text { Int (Miconia barbinervis, Piper sancti-felices, } \\
\text { Piper culebranum) }\end{array}$ & $\begin{array}{l}\text { A; no B - Medium } \\
\text { A; no B - Medium } \\
\text { A; no B - Medium }\end{array}$ \\
\hline Denslow et al., 1998 & Fertilisation and Gaps & Tropical wet forest (Costa Rica) & $\begin{array}{l}\text { Tol (Miconia multispicata, Miconia gracilis) } \\
\text { Mid (Miconia nervosa) } \\
\text { Int (Miconia affinis) }\end{array}$ & $\begin{array}{l}\text { A; no B - Low } \\
\text { A; no B - Low } \\
\mathrm{A}=\mathrm{B}-\text { Medium }\end{array}$ \\
\hline Ostertag, 1998 & $\begin{array}{l}\text { Trenching and Gaps in medium } \\
\text { and poor soils }\end{array}$ & $\begin{array}{l}\text { Tropical wet forest (Costa Rica) } \\
\text { Tropical residual forest (Costa Rica) }\end{array}$ & Int (Hampea appendiculata) & $\begin{array}{l}\text { A; no B - Medium } \\
\mathrm{A}>\mathrm{B}-\text { Medium }\end{array}$ \\
\hline Putz and Canham, 1992 & Trenching and Gaps & $\begin{array}{l}\text { Temperate abandoned rich area (New York, } \\
\text { USA) }\end{array}$ & Tol (Acer rubrum) & A; no B - Low \\
\hline Gerdol et al., 2002 & $\begin{array}{l}\text { Fertilisation and Above-ground } \\
\text { clearing }\end{array}$ & Temperate heath (Italy) & $\begin{array}{l}\text { Int? (Vaccinium myrtillus, Vaccinium } \\
\text { uliginosum) }\end{array}$ & A; no B - Medium \\
\hline Grubb et al., $1996^{\wedge}$ & $\begin{array}{l}\text { Rich and poor soil samples and } 4 \\
\text { contrasting light regimes (from } 0.3 \\
\text { to } 63 \% \text { PPFD) }\end{array}$ & $\begin{array}{l}\text { Temperate scrubland (Rich-fertile) } \\
\text { Temperate grassland (Poor: low P and N) }\end{array}$ & $\begin{array}{l}\text { Tol (Euonymus europaeus, Rhammus } \\
\text { cartharticus, Viburnum opulus, Viburnum lan- } \\
\text { tana, Fagus sylvatica) } \\
\text { Mid (Cornus sanguinea, Crataegus } \\
\text { monogyna, Ligustrum vulgare, Juniperus } \\
\text { communis, Rosa canina) }\end{array}$ & $\begin{array}{l}\text { A }>\text { B - Medium } \\
\text { A }>\text { B - Medium }\end{array}$ \\
\hline Holl, 1998 & $\begin{array}{l}\text { Trenching and Above-ground } \\
\text { clearing }\end{array}$ & Tropical abandoned pasture (Costa Rica) & Int (Calophyllum brasiliense) & A > B - Medium \\
\hline Canham et al., 1996 & $\begin{array}{l}\text { Fertilisation and Contrasting light } \\
\text { regimes }\end{array}$ & Temperate substrate & Tol (Acer saccharrum) & A $>$ B - Medium \\
\hline Dalling and Tanner, 1995 & Fertilisation in rich-closed site & Tropical rain forest (Jamaica) & $\begin{array}{l}\text { Int (Alchornea latifolia, Clethra occidentalis, } \\
\text { Vaccinium meridionale) }\end{array}$ & A > B - Medium \\
\hline Lewis and Tanner, 2000 & Trenching and Gaps & Tropical central Amazonian forest (Brazil) & $\begin{array}{l}\text { Tol (Aspidosperma carapanauba) } \\
\text { Int (Dinizia excelsa) }\end{array}$ & $\begin{array}{l}\mathrm{A}=\mathrm{B}-\text { Medium } \\
\mathrm{A}=\mathrm{B}-\text { High }\end{array}$ \\
\hline Peace and Grubb, $1982^{\wedge}$ & Fertilisation and 4 light regimes & Temperate woodland forest (England, U.K.) & Int (Impatiens parviflora) & $\mathrm{A}=\mathrm{B}-$ Low \\
\hline Putz and Canham, 1992 & Trenching and Gaps & $\begin{array}{l}\text { Temperate abandoned medium area (New } \\
\text { York, USA) }\end{array}$ & $\begin{array}{l}\text { Tol (Acer rubrum) } \\
\text { Mid (Fraxinus americana) }\end{array}$ & $\begin{array}{l}\mathrm{A}=\mathrm{B}-\text { Low } \\
\mathrm{A}=\mathrm{B}-\text { Low }\end{array}$ \\
\hline Latham, $1992^{\wedge}$ & Fertilisation and Light regimes & Sand/Peat/Vermiculite $(1 / 3 ; 1 / 3 ; 1 / 3)$ & $\begin{array}{l}\text { Tol (Fagus grandifolia, Nyssa sylvatica) } \\
\text { Mid (Castanea dentata, Quercus rubra) } \\
\text { Int (Carya tomentosa, Liriodendron } \\
\text { tuliîfera) }\end{array}$ & $\begin{array}{l}\mathrm{A}=\mathrm{B}-\text { Low } \\
\mathrm{A}=\mathrm{B}-\text { Medium } \\
\mathrm{A}=\mathrm{B}-\text { Medium }\end{array}$ \\
\hline Dillenburg et al., 1993 & $\begin{array}{l}\text { Trenching and Above-ground space } \\
\text { partitioning in open area }\end{array}$ & Temperate open forest (Maryland, USA) & $\begin{array}{l}\text { Int (Liquidambar styracifluca) versus vines } \\
\text { (Lonicera japonica, Parthenocissus } \\
\text { quinquefolia) }\end{array}$ & $\mathrm{A}<\mathrm{B}-$ Medium \\
\hline Horn, 1984 & Trenching and Gaps & $\begin{array}{l}\text { Temperate hardwood forest } \\
\text { (North Carolina, USA) }\end{array}$ & $\begin{array}{l}\text { Tol (Acer rubrum) } \\
\text { Mid (Cornus florida) }\end{array}$ & $\begin{array}{l}\mathrm{A}>\mathrm{B}-\text { Low } \\
\mathrm{A}<\mathrm{B}-\text { Medium }\end{array}$ \\
\hline Dalling and Tanner, 1995 & Fertilisation in poor-open site & Tropical mountain landslide (Jamaica) & $\begin{array}{l}\text { Int (Alchornea latifolia, Clethra occidentalis, } \\
\text { Vaccinium meridionale) }\end{array}$ & $\mathrm{A}<\mathrm{B}-$ Medium \\
\hline Christy, 1986 & Trenching and Gaps & Temperate mixed forest (Oregon, USA) & Tol (Tsuga heterophylla) & $\mathrm{A}<\mathrm{B}-$ Low \\
\hline Coomes and Grubb, 1998 & Trenching and Gaps & Tropical nutrient starved forest (Venezuela) & Gradient of tolerance (14 sp.) & $\begin{array}{l}\mathrm{A}<\mathrm{B}-\text { Low to } \\
\text { Medium }\end{array}$ \\
\hline Bauhus et al., 2000 & $\begin{array}{l}\text { Contrasting proportion of planted } \\
\text { trees in open area }\end{array}$ & Dry mixed forest (Australia) & Int (Eucalyptus globulus, Acacia mearnsii) & $\mathrm{A}<\mathrm{B}-$ Medium \\
\hline Jäderlund et al., 1997 & $\begin{array}{l}\text { Above- and below-ground space } \\
\text { partitioning }\end{array}$ & Northern boreal forest (Sweden) & Tol (Picea abies) & $\mathrm{A}<\mathrm{B}-$ High \\
\hline Wilson, 1993 & Plantation in open grassland & Grassland snowy mountain (Australia) & Int (Eucalyptus pauciflora) & $\mathrm{A}<\mathrm{B}-\mathrm{High}$ \\
\hline Putz and Canham, 1992 & Trenching and Gaps & $\begin{array}{l}\text { Temperate abandoned nutrient poor area } \\
\text { (New York, USA) }\end{array}$ & Tol (Acer rubrum) & B; no A - Low \\
\hline Kadmon, $1995^{\text {II }}$ & $\begin{array}{l}\text { Watering in a natural gradient of } \\
\text { soil moistures }\end{array}$ & Sandy Mediterranean area (Israel) & Unkown tol (Stipa capensis) & B; no A - Hight \\
\hline $\begin{array}{l}\text { Pantastico-Caldas and } \\
\text { Venable, } 1993 \mathbb{\Psi l}\end{array}$ & $\begin{array}{l}\text { Natural gradient of soil moistures } \\
\text { along a hill }\end{array}$ & Dry desert (Arizona, USA) & $\begin{array}{l}\text { Unkown tol (Plantago patagonica) } \\
\text { Unkown tol (Pectocarya recurvata) }\end{array}$ & $\begin{array}{l}\text { B; no A-Medium } \\
\text { B; no A-Medium }\end{array}$ \\
\hline
\end{tabular}

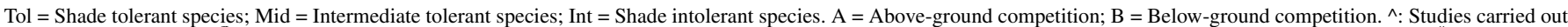

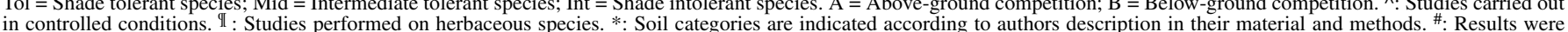
standardised and represent first Above- and Below-ground competition rank and second the impact of competition(s) on species performance. 
Acknowledgments: We thank S. Cousineau, N. Renfer, I. Aubin and D. Girard for assistance with field work, and S. Parent, I. Aubin, L. Ruddick, and C. Malo for commenting on the manuscript. The financial support of the Natural Sciences and Engineering Research Council of Canada is gratefully acknowledged.

\section{REFERENCES}

[1] Baker F.S., A revised tolerance table, J. For. 47 (1949) 179-181.

[2] Bauhus J., Khanna P.K., Menden N., Aboveground and belowground interactions in mixed plantations of Eucalyptus globulus and Acacia Mearnsii, Can. J. For. Res. 30 (2000) 1886-1894.

[3] Beaudet M., Messier C., Growth and morphological responses of yellow birch, sugar maple and beech seedlings growing under a natural light gradient, Can. J. For. Res. 28 (1998) 1007-1015.

[4] Beaudet M., Messier C., Hilbert D.W., Lo E., Wang Z., Lechowicz M.J., Leaf and plant level carbon gain in Yellow Birch, Sugar Maple and American Beech seedlings from contrasting forest light environments, Can. J. For. Res. 30 (2000) 390-404.

[5] Bellefleur P., LaRocque G., Compétition pour le rayonnement solaire en début de succession secondaire dans une érablière à bouleau jaune et hêtre, Can. J. For. Res. 13 (1983) 514-521.

[6] Bellefleur P., LaRocque G., Comparaison de la croissance d'espèces ligneuses en milieu ouvert et sous couvert forestier, Can. J. For. Res. 13 (1983) 508-513.

[7] Bellefleur P., Pétillon Y., Expérimentation sur la compétition interspécifique par élimination sélective d'espèces forestières, Can. J. For. Res. 13 (1983) 522-532.

[8] Bonser S.P., Aarssen L., Plastic allometry in young sugar maple (Acer saccharum): adaptive responses to light availability, Am. J. Bot. 81 (1994) 400-406.

[9] Burslem D.F.R.P., Grubb P.J., Turner I.M., Responses to nutrient addition among shade-tolerant tree seedlings of lowland tropical rain forest in Singapore, J. Ecol. 83 (1995) 113-122.

[10] Canham C.D., Suppression and release during canopy recruitment in Acer saccharum, Bull. Torrey Bot. Club. 112 (1985) 134-145.

[11] Canham C.D., Growth and canopy architecture of shade tolerant trees: response to canopy gaps, Ecology 69 (1988) 786-795.

[12] Canham C.D., Different responses to gaps among shade-tolerant tree species, Ecology 70 (1989) 548-550.

[13] Canham C.D., Suppression and release during canopy recruitment in Fagus grandifolia, Bull. Torrey Bot. Club. 117 (1990) 1-7.

[14] Canham C.D., Denslow J.S., Platt W.J., Runkle J.R., Spies T., White P.S., Light regimes beneath closed canopies and tree-fall gaps in temperate and tropical forests, Can. J. For. Res. 20 (1990) 620-631.

[15] Canham C.D., Berkowitz A.R., Kelly V.R., Lovett G.M., Ollinger S.V., Schnurr J., Biomass allocation and multiple resource limitation in tree seedlings, Can. J. For. Res. 26 (1996) 1521-1530.

[16] Chapin F.S., The mineral nutrition of wild plants, Annu. Rev. Ecol. Syst. 11 (1980) 233-260.

[17] Christy E.J., Effect of root competition and shading on growth of suppressed western hemlock (Tsuga heterophylla), Vegetatio 65 (1986) 21-28.

[18] Coomes D.A., Grubb P.J., Responses of juvenile trees to aboveand belowground competition in nutrient-starved Amazonian rain forest, Ecology 79 (1998) 768-782.

[19] Coomes D.A., Grubb P.J., Impacts of root competition in forests and woodlands: a theoretical framework and review of experiments, Ecol. Monogr. 70 (2000) 171-207.

[20] Dalling J.W., Tanner E.V.J., An experimental study on landslides in montane rain forest in Jamaica, J. Ecol. 83 (1995) 55-64.

[21] Denslow J.S., Schultz J.C., Vitousek P.M., Strain B.R., Growth responses of tropical shrubs to treefall gap environments, Ecology 71 (1990) 165-179.
[22] Denslow J.S., Ellison A.M., Sanford R.E., Treefall gap size effects on above- and belowground processes in tropical wet forest, J. Ecol. 86 (1998) 597-609.

[23] Dillenburg L.R., Whigham D.F., Teramura A.H., Forseth I.N., Effect of below- and aboveground competition from vines Lonicera japonica and Parthenocissus quinquefolia on the growth of the tree host Liquidambar styraciflua, Oecologia 93 (1993) 48-54.

[24] Elliott K.J., White A.S., Effects of competition from young northern hardwoods on red pine seedling growth, nutrient use efficiency, and leaf morphology, For. Ecol. Manage. 57 (1993) 233-255.

[25] Ellsworth D.S., Reich P.B., Leaf mass per area, nitrogen content and photosynthetic carbon gain in Acer saccharum seedlings in contrasting forest light environments, Funct. Ecol. 6 (1992) 423 435.

[26] Ellsworth D.S., Reich P.B., Canopy structure and vertical patterns of photosynthesis and related leaf traits in a deciduous forest, Oecologia 96 (1993) 169-178.

[27] Environment Canada., Canadian climate normals, Temperature and precipitation 1951-1980 Québec, Aymospheric Environment Service, Ottawa. 1982.

[28] Erdmann G.G., Betula alleghaniensis Britton, Yellow Birch. Burns R.M., Honkala B.H. (Eds.), Silvics of North America: Hardwood, Vol. 2, Washington, E.U. Forest service, 1990, pp. 133-147.

[29] Finzi A.C., Canham C.D., Sapling growth response to light and nitrogen availability in a southern New England forest, For. Ecol. Manage. 131 (2000) 153-165.

[30] Forcier L.K., Reproductive strategies and the co-occurrence of climax tree species, Science 189 (1975) 808-811.

[31] Fowler N., The role of competition in plant communities in arid and semiarid regions, Annu. Rev. Ecol. Syst. 17 (1986) 89-110.

[32] Gendron F., Messier C., Comeau P.G., Comparison of various methods for estimating the mean growing season percent photosynthetic photon flux density in forest, Agric. For. Meteor. 91 (1998) 55-70.

[33] Gerdol R., Brancaleoni L., Marchesini R., Bragazza L., Nutrient and carbon relations in subalpine dwarf shrubs after neighbour removal or fertilization in northern Italy, Oecologia 130 (2002) 476-483.

[34] Gleeson S.K., Tilman D., Plant allocation and the multiple limitation hypothesis, Am. Nat. 139 (1992) 1322-1343.

[35] Godman R.M., Yawney H.W., Tubbs C.H., Acer saccharum March, Sugar Maple, in: Burns R.M., Honkala B.H. (Eds.), Silvics of North America: Hardwoods, Vol. 2, Washington, E.U. Forest service, 1990, pp. 78-91.

[36] Goulet F., Bellefleur P., Leaf morphology plasticity in response to light environment in deciduous tree species and its implication on forest succession, Can. J. For. Res. 16 (1986) 1192-1195.

[37] Grubb P.J., Lee W.G., Kollmann J., Wilson B., Interaction of irradiance and soil nutrient supply on growth of seedlings of ten European tall-shrub species and Fagus sylvatica, J. Ecol. 84 (1996) 827-840.

[38] Holl K.D., Effect of above- and below-ground competition of shrubs and grass on Calophyllium brasiliense (Camb.) seedling growth in abandoned tropical pasture, For. Ecol. Manage. 109 (1998) 187-195.

[39] Horn J.C., Responses of understory tree seedlings to trenching, Am. Nat. 114 (1984) 252-258.

[40] Järderlund A., Zackrisson O., Dahlberg A., Nilsson M.-C., Interference of Vaccinium myrtillus on estabhishment, growth, and nutrition of Picea abies seedlings in a northern boreal site, Can. J. For. Res. 27 (1997) 2017-2025.

[41] Kadmon R., Plant competition along soil moisture gradients: a field experiment with the desert annual Stipa capensis, J. Ecol. 83 (1995) 253-262.

[42] Latham R.E., Co-occurring tree species change rank in seedling performance with resources varied experimentally, Ecology 73 (1992) 2129-2144. 
[43] Lewis S.L., Tanner E.V.J., Effects of above- and belowground competition on growth and survival of rain forest tree seedlings, Ecology 81 (2000) 2525-2538.

[44] Messier C., Puttonen P., Spatial and temporal variation in the light environment of developing Scots pine stands: the basis for a quick and efficient method of characterizing light, Can. J. For. Res. 25 (1995) 343-354.

[45] Newman E.I., Competition and diversity in herbaceous vegetation, Nature 244 (1973) 244-310.

[46] Ostertag R., Belowground effects of canopy gaps in a tropical wet forest, Ecology 79 (1998) 1294-1304.

[47] Pacala S.W., Canham C.D., Silander J.A. Jr., Kobe R.K., Sapling growth as a function of resources in a north temperate forest, Can. J. For. Res. 24 (1994) 2172-2183.

[48] Pantastico-Caldas M., Venable D.L., Competition in two species of desert annuals along a topographic gradient, Ecology 74 (1993) 2192-2203.

[49] Parent S., Messier C., A simple and efficient method to estimate microsite light availability under a forest canopy, Can. J. For. Res. 26 (1996) 151-154.
[50] Peace W.J.H., Grubb P.J., Interaction of light an mineral nutrient supply in the growth of Impatiens parviflora, New Phytol. 90 (1982) 127-150.

[51] Putz F.E., Canham C.D., Mechanisms of arrested succession in shrublands: root and shoot competition between shrubs and tree seedlings, For. Ecol. Manage. 49 (1992) 267-275.

[52] Riegel G.M., Miller R.F., Krueger W.C., The effect of aboveground and belowground competition on understory species composition in a Pinus ponderosa forest, For. Sci. 41 (1995) 864-889.

[53] Tilman D., Mechanisms of competition for nutrients and light, in: Tilman D. (Ed.), Plant Strategies and the Dynamics and Structure of Plant Communities, Princeton Academic Press Ed., Princeton New Jersey: Princeton University Press, 1988, pp. 52-97.

[54] Tubbs C.H., Houston D.R., Fagus grandifolia Ehrh. American beech, in: Burns R.M., Honkala B.H. (Eds.), Silvics of North America: Hardwoods, Vol. 2, Washington, E.U. Forest service, 1990, pp. 325-332.

[55] Wilson J.B., Shoot competition and root competition, J. Appl. Ecol. 25 (1988) 279-296

[56] Wilson S.D., Competition and resource availability in heath and grassland in the snowy mountains of Australia, J. Ecol. 81 (1993) $445-451$.

To access this journal online: www.edpsciences.org 